\title{
The Progress of Students Reading Comprehension through Wordless Picture Books
}

Romaida Lubis*

English Applied Linguistics Study Program State University of Medan, Indonesia

Corresponding Author: Romaida Lubis, E-mail: lubis.romaida@yahoo.com

\section{ARTICLE INFO}

Article history

Received: December 01, 2017

Accepted: January 09, 2018

Published: February 28, 2018

Volume: 9 Issue: 1

Advance access: January 2018

Conflicts of interest: None

Funding: None

Key words:

Ordless,

Implicitly,

Explicitly,

Interpretation,

Transacting

\begin{abstract}
Wordless picture book is an unique book that could help the young learner to get their literacy. The content of the wordless picture book must be communicated through the visual of the illustration. This research discusses a case study of how a kid of six years old produce his narrative through wordless picture book. The kid allowed to see and say on the page and then write the words that he has mentioned. Practicing to read repeatedly which increase fluency will improve his reading comprehension and written expression. This research was conducted to make better understand about the sense - making process that happen when a child works with the wordless picture book. Most sentences or texts were made based on the references and experience from daily life either explicitly or implicitly. In reading wordless book, readers faced the variety of visual signs. These sign systems help reader form a type of framework that show their interpretation of the text and helps them build construction of the story. The researcher wanted to make the reader understand better about the strategies that the child use to make sense of wordless text. The reason of this study is to help how a six year old nonreader would give interpretation to visual cues in wordless picture books. Transacting with the visual text in the books helped the child to make sense of the stories. The data were analyzed based on the principles of qualitative content analysis that involve a systematic review of the data, coding, category construction and analysis. The result of this research is the wordless picture books give opportunity to the children to create the story on their own and to bring in their own understanding of the world to the text.
\end{abstract}

\section{INTRODUCTION}

\section{Background of study}

Teaching a child to read by spelling the letters and sounding the phonics is not the guarantee for them to be able to read easily. Introducing to students the wordless picture book is good for them to make them understand the concept of a book. By transacting the wordless picture book the reader can develop their understanding about what is the content of the book and what information that the book present. It will be more fun for the students if there is no text in the book, so they can build their own interpretation about the book and this will enrich their vocabularies. According to Tiedt (2000), he recommends the use of wordless books for students even in the middle school. Students at the early stages of literacy development can use these books as ways to develop vocabulary, oral language, and self-expression. Second language learners can use them as a way to build the connection between their native language and English. Because of this study researched readings books which contained an ordinary printed text, as well as illustration, it is supposed that the effect of visual cues would be more exhaustive in the construction of meaning based on a wordless text. Wordless picture books could conduct to more different type of readings and be more open to a range of interpretation than books with text.

\section{Objective of the study}

This research was conducted to make better understand about the sense- making process that happen when a child works with the wordless picture book. In this research, a six-years old nonreader was asked to share his reading of wordless picture books with the researchers. The researchers wanted to know about the better strategies used by the child to make sense when he is reading the wordless picture book.

\section{Research Question}

1. How are the characters and visual features in wordless picture books responded by the child?

2. How does the child produce better narrative through wordless picture books?

\section{LITERATURE REVIEW}

Wordless picture book consider as an unique genre of text because the content of wordless picture book must be communicated through the use of illustration. The reading of wordless picture book is an open-ended process which is the reader could make their interpretation to the illustration based on the background of their experience and they could create their own story based on the illustration provided. 
Constructing meaning and building their own narratives is a basis provided by wordless picture book. Variety of visual signs are faced by the readers of wordless picture books. They then assign meaning to these visual signs based on their own experiences, perspectives, and the particular context of the reading event. These sign systems help readers form a type of framework that informs their interpretation of the text and helps them shape their construction of the story (Nodelman, 1988). Similarly, Elster's (1998) study of influences on children's emergent readings of picture books showed that visual cues had a significant impact on their readings and that readers' understanding of text was greatly supported by illustrations. Studies such as these supported the belief that reading is a meaning-making experience and that this meaning-making process is supported and facilitated by children's ability to respond to visual cues within the text. Since these studies investigated readings of books that contained a conventional printed text, as well as illustrations, it is assumed that the effects of visual cues would even be more profound in the construction of meaning based on a wordless text. As Nodelman (1988) stated that if the reader told the story of wordless picture book, they have their own right to make meaning based on their own experience and they have right for it and nothing wrong with that. Thus, wordless books, "which do not have this type of print story line to amplify or clarify the message of the illustrations, are by nature less corrective" (Crawford \& Hade, 2000, p.69). Wordless picture books then could lead to more divergent types of readings and may be more open to a range of interpretations than books that are accompanied by text.

\section{RESEARCH METHODOLOGY}

This research was conducted in qualitative research.

\section{Participant}

The participant of the study is Daniel, a six-years old nonreader. In July, Daniel started his year 1 in a public school in Medan, North Sumatera and a diagnostic test conducted by the school revealed that Daniel, after some weeks of school, does not have the ability to read in his first language which is Bahasa Indonesia. A diagnostic test at a learning center for English, reported that Daniel's reading ability in English is not strong although he knows many single words and was able to provide lots of English words when shown with pictures. For example, Daniel was able to fill in letters that were missing in an alphabet exercise. Semi-formal exercises requiring sentence reading (joining lines from sentences to pictures) and sentence completion (filling in missing words to pictures) were difficult for him.

Understanding verbal questions and responding to these questions are not problem for him in his school. For example, when he asked to name the color of the orange, he was able to give the answer "orange" without any hesitation. When the teacher asked him to lift up the paper from the table, he could do the instruction well and correctly. When the teacher gives him general instruction, he could understand and able to convey the instruction to his mother. For instance, every
Tuesday is physical exercise schedule in his classroom, and he could convey about preparing the clothes for sports to his mother well. In preschool, his teacher always gave him some activities based on his interests, such as drawing. He was also very detailed in his drawing. He would draw elements where most children would not have even noticed or would not have even thought of drawing. For instance, when he was drawing the house, he would try to draw every room found in every house and he could draw it in detailed. Nevertheless, Daniel was reluctant with literacy tasks especially those that did not come easily for him, and he preferred to discuss the pictures than struggle to decode the text. At home (according to his mother), a way to motivate him to engage in text-related activities is to allow him to draw once he finishes the text-related activities or in between those activities

\section{Data Collection and Analysis}

Data collection was done in four sessions involving the researchers and the child in the child's room and sometimes we did it in the library and classroom, with each complete session lasting approximately 30 minutes. The child was presented with a selection of six different wordless picture books. They are:

1. The flower man by Marie Rippel

2. Anno's journey by Marie Rippel

3. Frog, Where are you by Mercer Mayer

4. The lion and the mouse by Jerry Pinkney

5. Noah's Ark by Peter Spier

6. Red Sled by Lita Judge

The writers and illustrators of those books are foreign. The child explored and chose the book that he would like to read aloud. The child was asked to look through the book, read the story aloud, and share his understanding of the text based on the visual elements in the texts. This process was repeated four times, with the child reading a total number of 4 books. These four books are:

1. The flower man by Marie Rippel

2. Anno's journey by Marie Rippel

3. Frog, Where are you by Mercer Mayer

4. The lion and the mouse by Jerry Pinkney

During the sessions, the child was asked some questions and comments during the readings. The child's reading and corresponding discussions of the texts were recorded. Verbatim transcriptions, supplemented with researcher observations related to the child's intonations, facial expressions, and physical responses, were developed. For instance, the child's change of intonation in narrating the story and commenting on some of the characters in the story; the child's facial expressions when he was trying to comprehend and to make connections with some of the visual elements in the story; and the child's physical movements in narrating the story (hand movement, body movement) were noted. Document analysis of the wordless picture books used within the story as additional data. The data were then analyzed according to the principles of qualitative content analysis which involve a systematic review of the data, coding, category constructions, and analysis (Merriam, 1991). The transcripts and notes for the child's readings were first reviewed alongside 
the accompanying pages of the wordless book, in order to see which visual cues had captured the child's attention and elicited a response.

\section{FINDINGS}

The result of this study is to learn how a six-year old nonreader would respond to visual cues in wordless picture books. The child made sense of the stories by transacting with the visual texts in the books and assigning potential meanings to different signs encountered within the texts' frameworks. This sense-making process is categorized into three types and the findings of this study will be discussed in accordance with these categories.

\section{Sense-Making through Prior Knowledge and Experiences}

Good readers do not read in a vacuum rather they bring their prior knowledge and experiences to bear on their reading (Rosenblatt, 1987). In the case of Daniel, it was proved that he brought his prior knowledge and experience about a wide range of subject matter to bear on the reading of each story. In reading the four books, Daniel drew upon his prior knowledge in order to contextualize the signs that he encountered within the illustrations. For example, in reading The Flower Man by Marie Rippel, when Daniel saw the picture of flower in man's head, he said that the man on the book missed his wife so, he wanted to look for his wife and give the flower and the researcher asked him, "Why do you say that the old man wanted to give the flower to his wife", and then he said, "because my mommy like flowers". He said that his mommy ever told him that his mommy loved flower so much, so he remembered about what his mommy ever told before. Another example of Daniel bringing in his prior knowledge to understand the context of the illustration in The Flower Man by Marie Rippel is when he saw the picture of an old man carrying an umbrella. He was able to say it was a picture of hook to hang his sweater, because in the picture, his sweater is wet so in his mind the umbrella is for hanging the man's sweater. When the researcher asked him why say so, he answered that his daddy always hang his jacket, sweater, or cap on the place like umbrella at home.

When asked if he knew the name of the object, he said no. Sometimes the lack of prior knowledge also caused Daniel great difficulty in interpreting or at times he misinterpreted the visual cues in the illustrations. When the researcher told him that it was an umbrella, he replied that the umbrella could be used as a hanging clothes also. For example, when he was asked to describe the picture of the lion in The Lion and The Mouse by Pinkney, he was able to say that the picture that he saw is a sun because the color is orange and the shape is almost circle. When the researcher explained that is the picture of the head of the lion, he criticized the researcher that if the picture is the head of lion, it must have the eyes and the eyes must be black. He did not agree if the eyes of the lion is orange. The wordless picture book also facilitated the reader to be more criticism. When Daniel was faced with a concept that he was not familiar with, he also had difficulty interpreting the visual cues in the book. When reading Frog, where are you by Mercer Mayer, he kept asking about the frog. In his mind, frog never be a pet, he got knowledge that the various of pet are puppy, kitty, and so on. Most of the time, when Daniel described the illustration of the wordless picture book, it was always influenced by his prior knowledge. Daniel's choice of words in describing the illustrations is also very much influenced by his prior knowledge. He said that all the old man will be left by his wife alone if the old man did not give his wife flowers every day. He expressed his feeling, because around 2 months ago, his mommy asked him to visit nursing home especially for man. So, his experience during in the nursing home influenced the way he respond the wordless picture book.

\section{Sense-Making through Intertextuality}

Most texts make references, either explicitly or implicitly, to other texts in our lives. Consequently, reading becomes a sense-making process that involves a layering of texts and meanings. Good readers are able to read new texts by applying their memories of other texts, and by determining the interrelationships among these texts (Meek, 1998; Stephens, 1990). In several instances of Daniel's storytelling, he referred to other texts in his attempt to make sense of the text that he was reading. For instance, in trying to explain the roof top of the house in the book Anno's Journey by Marie Rippel, he expressed that all the roof top in the picture is blue and triangle. He also explained the reason for the color of the rooftop, he said that because of the old man in the picture has purple flower so, all the color of the rooftop is purple. He explained the color of the rooftop house when the researcher asked him to read the book "Anno's journey". He got mixture information when the researcher asked him to read different book at the same time. Actually, the rooftop of the house in the book "Anno's Journey" is not purple but grey.

When he described the dog in the book The flower man by Marie Rippel, he described that the dog is small and jumped over the big beam. The description of the dog that he explained actually found in the book Frog, where are you by Marie Rippel. In describing the character of the boy in the book Frog, where are you, He said that the boy is so brave, and the boy is look like the hero that he watched from television, such as superman. Daniel showed how brave is superman to help people by lifting up his hand and run around his room. By connecting among books, television and other media, the children transformed what could have been a simple, linear storybook reading into a more complex, richly layered inter-textual experience (Crawford \& Hade, 2000).

\section{Sense-Making through Multiple Perspective-Taking}

By looking at the plot of the stories from the perspective of different characters within the same story will enhance the children's understanding of a book. (Crawford \& Hade, 2000). Daniel showed his ability to convey different perspective by supplying dialogues for some of the characters, although he did it from a third person point of view, but he did it consistently. For instance, in reading The flower man 
by Marie Rippel, he made short conversation for the scene where the old man asked his neighbor to help him. "Can you come here to help me?" and the neighbor said, "What can I do for you, old man?" he said that he need someone to move the stairs to get him closer to the rooftop. Daniel was able to make that dialogue because he saw the face of old man pale and need help. In Frog, where are you by Mercer Mayer, Daniel in describing the boy who has dog and frog as his pets, he said, “ My dog, my frog come on here, it's time for us to play, please do not sit there only. Daniel thought as if the frog did not want to play with him because the frog is in the can, but actually, can is the place for frog to be safe. Every time, Daniel told the story of each wordless picture book, he tried to be the characters of the story. Though this was not evident by the use of first-person perspectives in describing the story, it was prominent in his facial expressions and physical movements in his effort to narrate the stories. Daniel tried to cut the paper to make the letter " $S$ " for superhero and would do the flying movements (hands straight and body slightly slanting to the front) to describe the movements of Superman in Frog, where are you by Marie Rippel. In this case, he was no longer just trying to describe the character from a third-person point of view, he was actually trying to be the character.

\section{Sense - Making through Active, Playful Behaviors}

According to Lewis (2001) says that almost young children always play with what they are learning either with or without adult present. Daniel responded and shared his stories playfully. For instance, he made the noise sound and frightening face when he expressed his feeling about the lion. He also run everywhere around his room and he used many playful body movements and hand gestures in order to describe different scenes. To comprehend the presence of superhero, brave man and brave dog in The flower man by $\mathrm{Ma}$ rie Rippel, he jumped and lifted his hand above his head as if he made a superhero who was flying and he did it playful. Even though, he was accompanied by the researcher during telling his stories about the wordless picture book, and the researcher kept reminding him to be serious but he kept playing during describing the characters and telling the stories. He could tell the stories from each scene become funny and silly and finally laugh.

\section{CONCLUSION AND SUGGESTION}

This study has clearly shown that reading does not start with words. In this case, a child who is termed as nonreader has managed to comprehend stories without decoding texts. Grammatical sound and the mixture of English and Bahasa Indonesia as Daniel first language may not be considered his narratives, they were rich with references to the written word, visual images and his other experiences that made up his everyday life. According to Crawford and Hade (2000) that conducted about the children reading wordless picture book as the finding of this study. (Golden \& Gerber, 1990; Meek, 1998; Stephens, 1990, Lewis 2001; Fueyo, 1991) also investigated the children reading picture book. Both studies on wordless picture books and picture books indicate children rely on many of the same strategies for reading wordless, visual texts, as they do when reading texts that offer a combination of print and visual texts (Crawford \& Hade, 2000).

Pictures can be turned into words that rich narrative resources, if the reader change the meaning of the pictures. Nodelman 1988 states that narratives could be changed into the pictures. This is an important thing to note for it alerts us to the fact that although pictures and words in close proximity in the picture book influence each other, the relationship is never entirely symmetrical (Lewis, 2001) Children's reading of wordless picture books may provide a glimpse into their understanding of literacy-related activities, as well as insights into the sense-making processes they use when navigating texts. In general, children who is reading wordless picture book with multi-level and multi perspective understanding will have opportunity to improve their narrative and to be more criticism with the picture. Most importantly, these books give opportunity to the children to create the story on their own and to bring in their own understanding of the world to the texts.

\section{REFERENCES}

Cianciolo, P. J. (1984). Use wordless picture books to teach reading visual literacy and to study literature. In P. P. Barron \& J. Q. Burley (Eds.), Jump over the moon: Selected professional readings (pp. 138-144). New York: Holt, Rinehart, and Winston.

Considine, D. M. (1987). Visual literacy and the curriculum: More to it that meets the eye. Language Arts, 64, 634-640.

Crawford, P. A. \& Hade, D. D. (2000). Inside the picture, outside the frame: Semiotics and the reading of wordless picture book. Journal of Research in Childhood Education, 15(1), 66-80 [ED623711]

Degler, L. S. (1979). Putting words in wordless books. Reading Teacher,32, 399-402.

Early, M. (1991). Using wordless picture books to promote second language learning. ELT Journal Volume, 45(3), 245-251.

Ekpe, S.I., Egbe, G.B. (2005). Picture story as a creative connection between reading and writing. Thinking Classroom, 6(3), 27-35.

Fueyo, J. (1991). Reading "literate sensibilities": Resisting a verbocentric writing classroom. Language Arts, 68, 641-648.

Golden, J. \& Gerber, A. (1990). A semiotic perspective of text: The picture story book event. Journal of Reading Behavior, 22, 203-219

Henry, R., Simpson, C. (2001). Picture books \& older readers: A match made in heaven. Teacher Librarian, 28(3), 25-30.

Helman, L, \& Burns, M. (2008) What does oral language have to do with it? Helping young English-language learners acquire a sight word vocabulary. The Reading Teacher, 62(1), 14-19.

Lysaker, J. T. (2006). Young children's readings of wordless picture books: What's 'self' go to do with it? Journal of Early Childhood Literacy, 6(1), 33-55. 
Omotoso, S., \& Lamme, L. (1979). Using wordless picture books to assess cross-cultural differences in seven year olds. The Reading Teacher, 32(4), 414-416.

Meek, M. (1998). How texts teach what readers learn. Exeter, England: Thimble Press.

Reese, C. (1996). Story development using wordless picture books. The Reading Teacher, 50 (2), 172.

Smith, G. G. (2004). Stimulating critical thinking with wordless books. Ohio Reading Teacher, 36(1/2), 75-80.

\section{Children's Books Cited}

- Marie Rippel (2005) The Flower Man. London. Mark Ludy

- Marie Rippel (1997) Anno's journey. Boston

- Mercer Mayer (2003), Frog, Where are you. London

- Jerry Pinkney (2009), The Lion and The Mouse. London

- $\quad$ Peter Spier (2005), Noah's Ark. USA

- $\quad$ Lita Judge (2011), Red Sled. London. 